\title{
The Trade-offs Budget of Archipelagic Local Government in Indonesia
}

Moh Said ${ }^{1}$, Bambang Supriyono ${ }^{2}$, Mujibur Rahman Khairul Muluk ${ }^{3}$ and Bambang Santoso Haryono ${ }^{4}$

\begin{abstract}
This paper discusses the analysis of local government financial capacity for equitable development in its territory. Autonomy requires local governments to improve their abilities in various matters, such as organizational, financial, and political. Financial capacity is the key to achieving local government performance. Limited financial capacity results in an imbalance in the distribution of development. Budget allocations meet complicated conditions to maintain equitable development in all territories. The local government within the Indonesian archipelago faces great challenges to minimize regional disparities. "Success to the successful" (Kim \& Anderson, 1998) is an archetype that illustrates this reality. Local government budgets behave in trade-offs, between the mainland and the islands area negating each other in their allocations. Affirmations in one area result in weaker allocations in other areas. The dilemma is that local governments are committed to eliminating regional disparities but are not supported by adequate financial capacity. Low financial capacity causes a monopolistic pattern. If an entity leads, then the entity will be easier to continue to lead and improve its performance, while other entities remain underdeveloped.
\end{abstract}

JEL classification: L32, Z33

Keyword: Trade-offs Budget, Quality of Development, Archipelagic Local Government, Indonesia

\footnotetext{
${ }^{1}$ Doctoral Student of Faculty of Administrative Science, Universitas Brawijaya. said.mhj@gmail.com

${ }^{2}$ Faculty of Administrative Science, Universitas Brawijaya

${ }^{3}$ Faculty of Administrative Science, Universitas Brawijaya

${ }^{4}$ Faculty of Administrative Science, Universitas Brawijaya
} 


\section{Introduction}

The success of regional autonomy, besides being supported by the readiness of regulation, also needs the capacity of local government to perform their duties and functions. Said (2008, p.62) explains that the spirit of regional autonomy success is the capacity of local government. However, it is well-known that local government capacity is an obstacle for the achievement of good autonomy performance. In Indonesia, since the reformation begins, the spirit of regional autonomy has become stronger due to the enactment of the regional government law in 1999. The reformation has changed the accountability system of local government; one of them is accountability in financial management (Darwanis and Chairunnisa, 2013, p.151). After 20 years of decentralization, the problem of lack of capacity remains a serious problem for local government in Indonesia. One of the key capacities is finance. Budget allocation triggers controversy among government affairs (Adolph, Breunig, and Koski, 2018, p.5). Their results suggest that trade-offs budget occurs due to differences in priorities, political dynamics and oppositions, and demographic conditions.

The problem of disparity in budget allocation becomes more critical when it is faced with regional conditions that experience disparity. MacCallum et al (2009, pp.20-22), Khan and Muthallib (1982, p.7), and Bowon (2010, pp.1-2) state that the effectiveness of the public service delivery is significantly influenced by a country's or local governments' territorial conditions. Limited financial capacity that is in line with territorial challenges causes to worsen the distribution of development. In the end, it leads to disparity in development among regions. This study attempts to uncover the trade-offs budget of local governments that have archipelago territory. The local government in archipelagic area experiences severe challenges in performing development and distributing public services that effectively cover all regions. Geographical conditions lead to poor regional accessibility. These conditions give impact on the non-optimal management of all aspects of life in the archipelagic area. The farthest archipelagic area from the center of government experiences low accessibility, slow development, and low availability and quality of infrastructure.

By utilizing systems archetype basic modeling, this study formulates a system model of local government budget allocation in the archipelagic area. The use of systems archetype basic makes it easy to describe the complexity of the system so that it has a simple-yet-deep understanding (Kim and Anderson, 1998, p.vii). Moreover, Caffrey and Monro (2017, pp.3-4) state that the system approach is the right way to evaluate the complexity of the process. Systems archetype is considered as a modeling tool as well as a theoretical lens for analyzing local government budget in the archipelagic area. The successful archetype shows that budget allocation to the local government of the archipelagic area behaves in trade-offs budget.

\section{Literature Review}

\subsection{Decentralization and Autonomous Region}

Decentralization policy requires the establishment of autonomous region. The presence of autonomous region is as a strategy for the administration effectiveness of government in the region. The ideals of community welfare can be more easily achieved if the administration of government is closer to the community. The local government that becomes the milestone for the 
implementation of more precise services and development to meet the needs and expectations of the local community.

Decentralization is a transfer of authority from the central government to local government. Smith (1985, p.1) defines decentralization as a pattern of power relations at various levels of government. Hence, decentralization is frequently interpreted as the ownership of power to determine one's own destiny and manage it to achieve mutually-agreed goals. Then, Rondinelli (1999, pp.55-56) divides decentralization into four types namely: (a) Political Decentralization; (b) Administrative Decentralization; (c) Fiscal Decentralization; and (d) Economic or Market Decentralization.

A country that is more developing makes the differences among local governments inevitable. Worthington and Dollery (2001, p.2) state that in line with the development of a country, local government differences are also growing. Three big things that experience differences are demographics, employment, and infrastructure. This condition is not effective if it is regulated by uniform national standards. For Indonesia, it is not only the three aspects aforementioned that become differences among regions, but it is also coupled with geographical differences, namely the mainland and the archipelagic area. The archipelagic area is often left behind from the mainland in terms of development conducted by the local government. It happens because generally, the mainland is the center of government and the economy; therefore, the distribution of resources tends to accumulate in the mainland.

The implementation of local government must pay attention to three aspects, namely: political, fiscal, and institutional. Political factor includes adequate regulation. Clear regulation is regarding the division of authority between the central and local governments as well as the regulations derived from the technical implementation. Financial support is also an important factor. Financial support from the central government is in line with the delegation of authority and responsibilities of government affairs to the autonomous region. In addition, it is also related to the ability of autonomous regions to independently accumulate and mobilize regional finances. Besides, for institutional aspect, it includes the readiness of an autonomous regional institution to regulate and to manage their own affairs. Related to institutional capacity, it refers to the opinion of Parker (1995, p.44) which explains that the medium-term impact of decentralization can be seen from several elements, including: participation, accountability, transparency, resource mobilization, resource allocation, financial capacity, and institutional capacity.

Then, according to Naab (2005, p.48), to measure the effectiveness of the implementation of local government, it can be seen from the outcomes of development implementation and institutional capacity. Good local government institutional capacity will direct the work outcome that provides benefits to the community. The results of development implementation are seen from service infrastructure, accountability, participation, service responsiveness, human resources and finance. Initially, the development must be directed on the fulfillment of adequate infrastructure for the delivery of basic services. After it is fulfilled, it will be developed in other supporting infrastructure. The implementation of good public services based on the principles of accountability and respect and supported by adequate human and financial resources will obtain good results. Especially if the implementation is supported by the community in the frame of active participation. 


\subsection{Financial Capacity and Budget}

There are several things that must be considered in terms of fiscal decentralization which are: (a) the assignment of expenditure responsibility; (b) assignment of tax resources); (c) intergovernmental fiscal transfer); (d) subnational deficits, borrowing and debt (Mulyana, et al., 2006, p.26). Then, Tangkilisan (2005, p.31) and Silaban (2002, p.2) also explains that to be able to have adequate financial capacity, a region needs sufficient financial resources as well. Associated with financial sources that can be made by local governments, it is sourced from local taxes and tax distribution from the central government, loans from third parties, and subsidies from the central government. The same thing is explained by Rondinelli $(1999, \mathrm{p} .2)$ that there are 5 (five) forms of fiscal decentralization namely: (a) self-financing or cost recovery through user charges; (b) cofinancing or co-production, in which users participate in providing services and infrastructure through monetary or labor contributions; (c) expansion of local revenues through property or sales taxes or indirect charges; (d) intergovernmental transfers of general revenues from taxes collected by the central government to local governments for general or specific uses; (e) Authorization of municipal borrowing and mobilization of national or local government resources through loan guarantees".

The form of fiscal decentralization as proposed by Rondinelli is slightly different from what is delivered by Mulyana, et al. (2006, p.29) in which it is divided into three forms, namely: (a) Full Decentralization, namely the delegation of responsibilities, authority and functions to the local government completely. Local governments must act in accordance with the rules and policies outlined by the central government but they still have freedom in determining how they conduct their duties, such as the acquisition and the use of funds and other resources; (b) Deconcentration, namely the central government performs its functions in the regions by using the resources and facilities provided by the central government. Deconcentration is a form of administration by the central government which is carried out within a certain regional area; (c) Co-administration; this form of decentralization is in the form of authority of the regional government to conduct the role and the function of the central government with the facilities provided by the central government.

The implementation of fiscal decentralization, according to Saragih (2003, p.39) must be understood as a comprehensive system. Local government financial management is based on the principle of money follows functions. Good monitoring and evaluation from the central government is needed. The success of fiscal decentralization is influenced by the tax capabilities of local governments. In addition, it also needs to be understood that the implementation of fiscal decentralization faces severe budget challenges. The even distribution of the budget becomes complicated when financial capacity is low. Besides, the efforts to realize good services and development in the local area are hampered. This makes the ideals of the community welfare realization is also slow (Naab, 2005, p.51; Hoessein, 2000, p.16).

Local government budget management is widely discussed by the experts which can be classified into two groups namely a group that focuses on the motivation of the allocation process (Rubin, 1997; Thurmaier and Willoughby, 2001), and a group that sees budget management in relation to politics, institutions, and economics (Krause and Melusky, 2012, pp.98-112; Lewis et al., 2015, pp.447-475). However, if it is understood, both expert groups have an estuary on the institutional capacity of the local government and economy. Regarding this paper, the reference for local 
government financial management looks at the financial capacity of local government related to the even distribution of budget, which is influenced by its territorial challenges.

\subsection{The Even Distribution of Budget and Catchment Area}

The area affordability at the territorial boundary of an area becomes a serious problem related to the management of services for the local community. Smith (1985, p.61) states that the consequence of decentralization is the formation of state divisions into areas. In Indonesia's case, the territorial division of the region is not based on the community served but it is based on the region. Therefore, the tendency is many regions have large areas with distributed community settlement system which result to the difficulties in the distribution of basic services to the community. Bennet (1980, p.56) and Smith (1985, p.62) provide an explanation of this that the territorial management of each region must be large enough to attract sufficient resources.

Furthermore, for Norton (1994, pp.46-47), a territorial arrangement is related to economic efficiency and democracy effectiveness. The combination of the two has significance to create stability, flexibility, and responsiveness. Economic efficiency considerations that become the basis of determining regional boundaries cover: low travel and communication costs; the extent to which local governments are able to meet financial, land and other resource needs from within their own regions so that it minimizes economic dependence, minimizes costs arising from activities in an area and triggers other costs; facilitates collaboration and coordination between services provided; adjusts the territory to private, voluntary and public bodies and related interests to facilitate cooperation and coordination for mutual and interdependent common interests.

A territorial boundary is often associated with overlapping considerations of the democracratic effectiveness and economic efficiency. This condition is caused by the expectation to guarantee the willingnesses of the voters; justice and representation for minorities; easy accessibility of the population in electing leaders; the range of powers and responsibilities that support local governments to respond to the needs of local communities, as well as to give choices in providing public needs. Regional boundary determination can also be based on catchment area as stated by Muluk (2009, p.108) that the optimal area for services, development, resources withdrawal, participation and control of both community and the bureaucracy. The importance of catchment area is related to the need for accurate boundary determination with quality administration oriented to deal with changes and complexity of community services. Through the clarity of a territorial boundary, it is expected that optimization of service provision to the public will occur. The condition caused by failure to reach the catchment area, or the opposite, is the discatchment area. This failure condition can cause loss and damage to the environment, social community, and trigger community dissatisfaction with services which are managed by the Central or Local Government.

Service coverage is affected by several factors such as area size, population, institutional capacity, facility and infrastructure, and the presence of other service institutions (Muluk, 2009, p.108). In order to guarantee the affordability of this service, the ideal division of regional government should be calculated according to the ideal. If there is a condition that the capacity of local government is not able to reach its people well for basic services, then the boundaries of the regions need to be reconsidered. Certainly, it is not an easy thing for the case of Indonesia where the formation of the majority local government has been as old as the Unitary State of the Republic of Indonesia. However, the right solution must still be considered so that the reality of this unreachability service 
(discatchment) can be overcome. However, the community has the same right to obtain proper public services, both those in the center of growth and those in the periphery or remote areas.

\section{Research Method}

This research was conducted in Sumenep Regency, Indonesia. The purpose of this research is to explain and to model the causality of local government budget management. Modeling uses basic archetype system. The use of this method aims to understand complex problems (Kim and Anderson, 1998, p.1). Basic archetype system is used to explore phenomena holistically to formulate appropriate solutions (Haines, 1998, p.25). Each archetype has different characteristics, special experiences, specific performance behavior patterns, structures, and different interventions. This system can quickly build simple systemic awareness (Kim and Lannon, 1997, p.2).

The data were collected by interview, focus group discussion, and data from related documents. The interviews were conducted with several informants who had knowledge and understanding of the focus of the research, including: Sumenep Regency Government apparatus, the Village Head and community leaders in the archipelagic area, and the members of community organizations. The Focus Group Discussion was conducted as an effort to triangulate the data to obtain valid data. Then, the validity of the data also refers to the opinion of Coyle (1996, p.96), stating that causal loop diagram must be in accordance with the problem, consistent with causal loops equations, and the model must be balanced and reasonable. The process of data analysis refers to the phases delivered by Kim and Anderson (1998, p.viii) in Figure 1.

\section{Listening for Storyline}

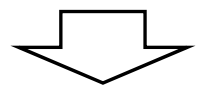

Briefly Summerrize The Archetypal Theme in The Story

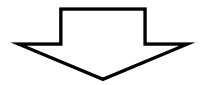

Identify Key Variable

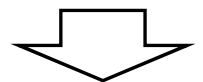

Graph The Behavior of Some of Those Variables Overtime
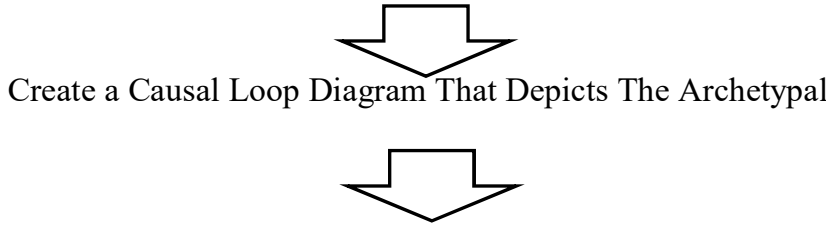

Systemic Structure Manifested by The Story

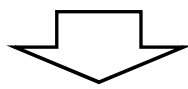

Choose Particular Archetype In Question 
Figure 1. Data Analysis Flow in the Systems Archetype Basic

\section{Research Findings}

Based on the results of interviews, FGDs, and data tracking from related documents, archetype of budget allocation was obtained in Sumenep Regency. The archetype was built by several subsystems, namely the budget allocation subsystem for the mainland, and the budget allocation subsystem for the archipelagic area. The budget allocation structure explains that the budget allocation made by the Sumenep Regency Government is influenced by several elements including: budget capacity, budget allocation, and development quality.

\section{a. Subsystem of Budget Allocation for Archipelagic Area}

In the subsystem of budget allocationfor the the archipelagic area, it has a tendency that the change the performance of each element in this budget allocation structure is dynamically strengthened marked by reinforcement on each factor (reinforcing). The relation formed explains that if the budget allocation for the implementation of governance in the archipelagic area increases, the success of the quality of the governance implementation in the the archipelagic area will also increase, so that the budget used in the the archipelagic area increases.

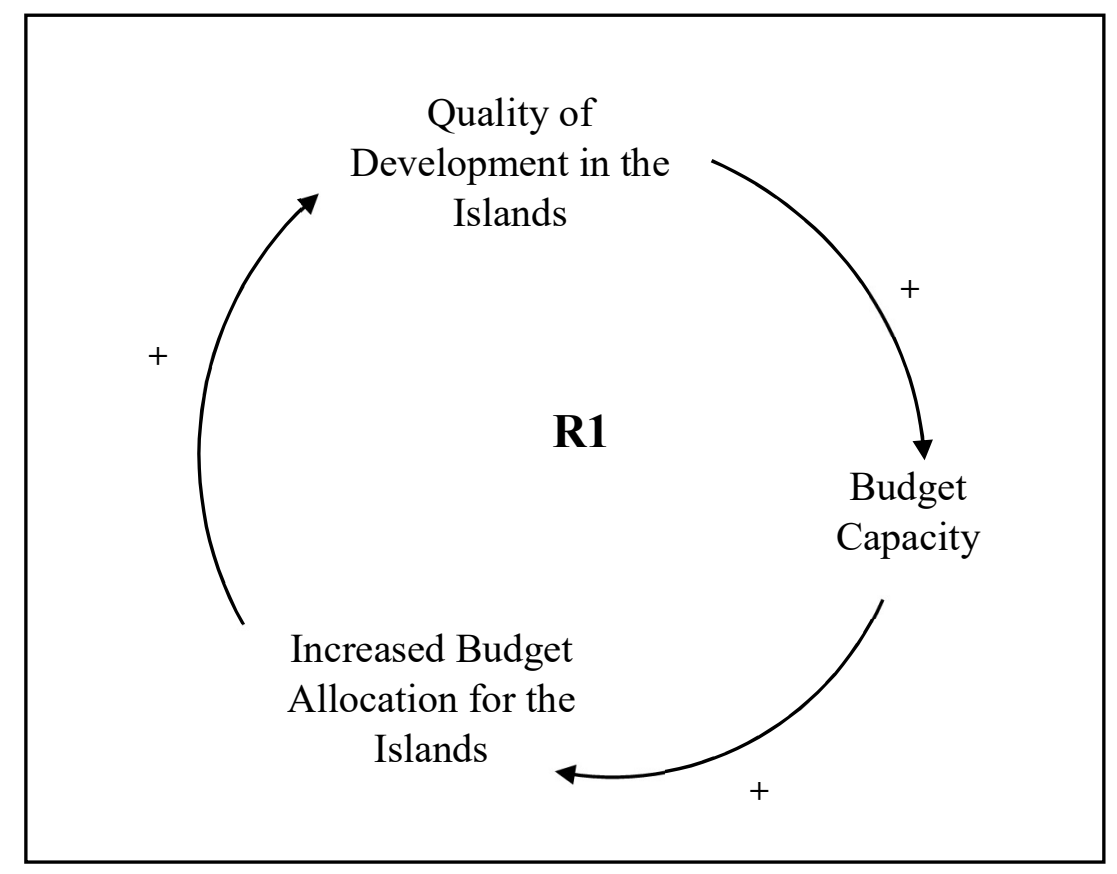

Figure 2. The Causality in The Budget Allocations of Islands

The budget allocation for the the archipelagic area shows that it has provided benefits in enhancing the quality of development implementation, especially in compulsory affairs that relate directly to basic services, namely education, health, and transportation infrastructure. The structure of the first causal relationship is "The stronger the budget capacity of the local government is, the greater the budget allocation for the archipelagic area." The structure of causality shows that to increase the budget allocation for each development period, it depends highly on the financial capacity of the 
local government. Therefore, to be able to allocate sufficient budget for each development effort, local governments must have adequate financial capacity.

The structure of the second causal relationship is "The more increasing the budget allocation is, the more increasing the quality of development in the archipelagic area". It means that the achievement of improving the development implementation quality in the the archipelagic area requires adequate budget allocation. By considering the condition of the the archipelagic area where the quality of basic services is inadequate, each development period is prioritized on compulsory affairs which are directly related to basic services. The need for quality basic services will continue to increase with the progress of community's lives. Enhancing the development quality in the the archipelagic area requires higher budget allocation in the following year. Hence, an increase in the development quality in the the archipelagic area needs increase in budget allocation.

In addition, the structure of the third causal relationship is "The more increasing the quality of development in the archipelagic area is, the more increasing the capacity of the local government budget". In the beginning, the development quality improvement in the the archipelagic area is focused on affairs related to basic services, then it is in line with its development. The more increasing the budget allocation, it will increase the number and the variety of development programs that can be improved in quality. It can also be stated that the increase of the budget allocation for the the archipelagic area has a positive effect on the success of quality development implementation in the the archipelagic area.

\section{b. Subsystem of Budget Allocation for Mainland}

The structure of causality in subsystem of budget allocation for the mainland area has characteristics that are reinforcing. The causal relationship between the elements formed explains that, if the budget allocation for the implementation of governance in the mainland increases, the success of the government implementation quality in the mainland will also increase, so that the budget used in the mainland increases as well.

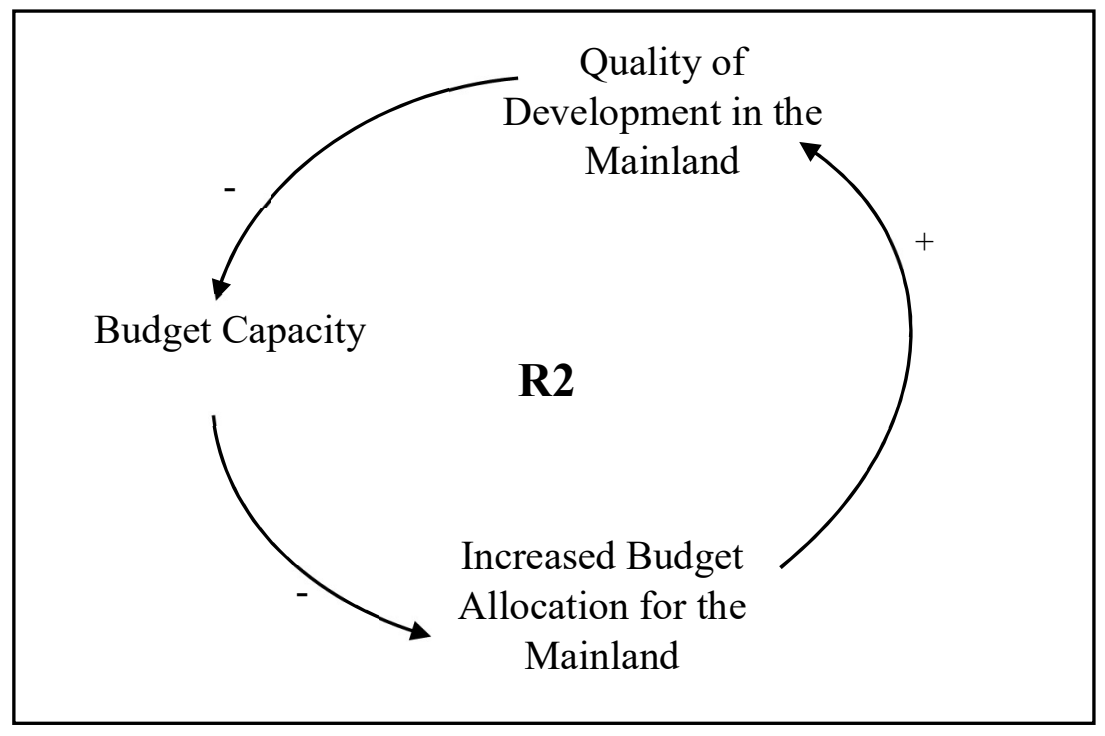

Figure 3. The Causality in The Budget Allocations of Mainland 
In the above structure. it can be known that the budget capacity of Sumenep Regency Government has a positive impact on improving the quality of development in the mainland. The first causal structure is "The stronger the budget capacity is, the higher the budget allocation for the mainland". The structure of the causal relationship shows that budget capacity results in the increase in budget allocations for development in the mainland. The result that arises is the benefit or positive influence for improving the quality of development implementation which encourages the quality of public services in the mainland.

The second causal relation is "The greater the budget allocation is, the more increasing the quality of development in the mainland area". The achievement of improving the development implementation quality in the mainland area is mostly determined by the amount of budget allocation for the region. The increase of the budget allocation for each period of development will encourage an increase in the quality of the delivery of government affairs and public services.

Furthermore, the third structure of causal relation is "The more increasing the quality of development in the mainland is, the stronger the local government budget capacity". The condition of the mainland, although the current condition is much better than the archipelagic area, it still needs adequate budget allocation to encourage its progress. The developed mainland in the future will have an impact on strengthening the capacity of the local government budget.

\section{c. The Archetype "Success to the Successful" Budget Capacity of Archipelagic Local Government}

"Success to the successful" is a situation in which two or more individuals, groups, projects, initiatives, etc are vying for a limited pool of resources to achieve success. If one of them starts to become more successful or is historically already more successful than others, it tends to garner more resources, thereby increasing the likelihood of continued success (Kim and Anderson, 1998, p.87). The archetype of "Success to the successful "can be achieved when one person (A) is given more resources, A then has a higher likelihood of succeeding than another person (B) -see Figure 4 The Success to the successful (Kim and Anderson, 1998, p.87).

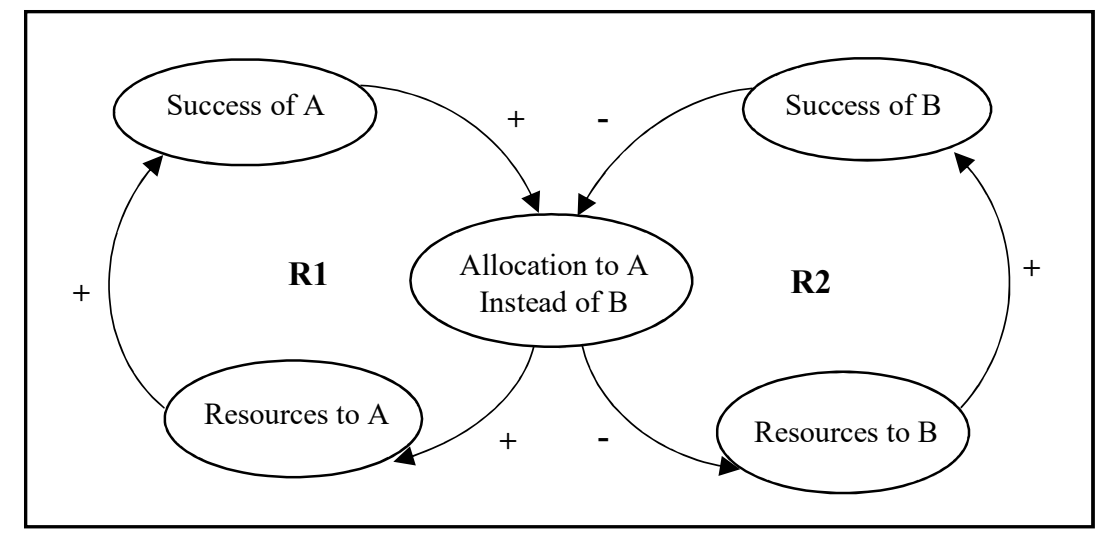

Figure 4. The Archetype "Success to the successful" from Kim and Anderson $(1998, p .87)$

The archetype of archipelagic local government budget capacity is obtained from the integration of the existing subsystems. The structure formed from integration results is in accordance with the 
characteristics of archetype success to the successful (Kim and Andeson, 1998, p.87). The archetype "success to the successful" has two reinforcing loops, which work together as one reinforcing loop. This phenomenon is explained by the archetype as a monopoly pattern. The long term (over time) behavior of this archetype is that if an entity is successful in an affair (funding), the entity will continue to be more successful which will easily to lead to, and to improve, its good performance. In the case of Sumenep Regency, if the budget allocation in the mainland is more dominant, the archipelagic area will experience budget shortages and vice versa. Consequently, the dominant region will keep leading in improving its performance, while other regions will experience underperformance. Development, which is dominated by the mainland, has resulted in slowing development in the archipelagic area.

The Archetype Success to the Successful in Figure 4 shows that the two entities negate each other. The budget allocation for one of the existing region makes other regions experience low allocations. This behavior is known as trade-off behavior in the budgeting system. The tendency of budget allocation occurs in the left loop, then the right loop decreases. If the budget is allocated more in the archipelagic area which will improve the quality of development in this region, then, at the same time, the priority or partiality of the budget allocation in the mainland will decrease. The increase or the decrease in budget allocation in each region will cause an increase or a decrease in the system performance in the region. This condition is not a system dynamics expected, because each region must continue to be built and to be grown in order to realize the welfare of the community. The enhancement of the development quality in the archipelagic area may not cause a decrease in quality in the mainland of Sumenep Regency.

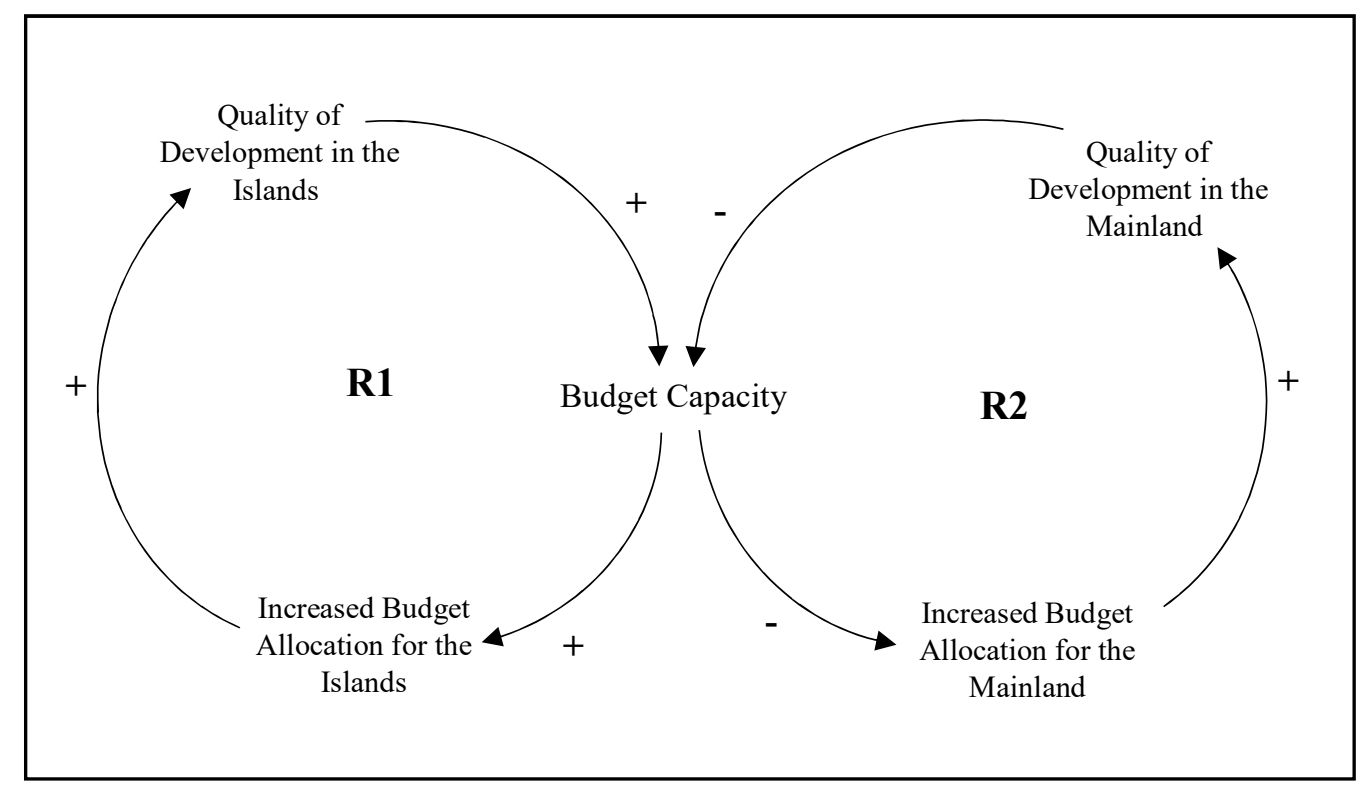

Figure 5. Archetype Success to the Successful for Budget Allocations of Archipelagic Local Government 


\section{Discussion}

The archetype finding provides a comprehensive description of budgetary capacity that affects development performance in archipelagic local governments. Various elements dynamically contribute to the implementation of development systems. The existing elements are interrelated and affect one another. Archetype success to the successful illustrates that the condition of budget allocation for the mainland and archipelago areas in Sumenep Regency is trade-offs budget. Budget capacity is the node of the existing system. The discussion on the dynamics of elements in the local development implementation system in Sumenep Regency refers to Said's (2008, p.62) opinion that the performance of local government is influenced by their capacity, specifically financial capacity. The elements found in this study reinforce the above opinion and add that the geographical conditions in the territorial local government are big challenges.

Local financial capacity is then influenced by budget allocations in two different regions. Budget needs are for the mainland and the archipelagic area. Balance in budget allocations in the two regions is the key to successful development. Nevertheless, limited budget capacity results in counter-interests in both regions. The condition of the archipelagic area that is left behind from the mainland needs a greater allocation in order to accelerate development. However, the development interests in the mainland cannot be negated immediately. Nonetheless, the development of the mainland must always be supported so that the community's lives keep improving.

The challenges of this geographical condition add to the budget burden for the development implementation in Sumenep Regency. The disparity in development occurs in two different regions, namely the mainland and the archipelagic area. The development disparity between the two regions could be the result of a disproportionate budget allocation. The issue of controversy over budget allocations in government affairs has been marked by (Adolph, Breunig, and Koski, 2018, p.5) which states that the behavior of trade-offs budget in a government is as a result of differences in priorities. However, the findings of this study indicate that the trade-offs budget becomes more difficult to be avoided by the Sumenep Regency Government as a consequence of the regional conditions that experience disparities. Budget allocation controversy occurs due to territorial challenges (MacCallum et al, 2009, pp.20-22 ; Khan and Muthallib, 1982, p.7; Bowon, 2010, pp.12). Limited financial capacity combined with territorial challenges leads to poorer budgetary allocations that hamper the even distribution of development distribution. The problem of tradeoffs budget in the local government of the archipelagic area is not only as a result of limited financial capacity, but it is worsened by the other entity, namely geographical condition. Furthermore, it can also be stated that disparity in budget allocation becomes the cause of institutional and economic problems (Krause and Melusky, 2012, pp.98-112; Lewis, et.al., 2015, pp.447-475). In the end, it causes a disparity between regions.

The trade-offs budget in Sumenep Regency can also be seen as a symptom of the discatchment area. Limited financial capacity coupled with challenges in geographical conditions has hampered the affordability of development and public services (Hoessein, 2000, p.16; and Muluk, 2009, p108). The continuous discatchment condition will have an impact on worsening dimensions of the local governance. Hence, new interventions are needed on the main element of financial capacity as the special policy that show partisanship for strengthening financial capacity so that budget allocations in the mainland and in the archipelagic areas are equally appropriate and adequate. 
Said, Supriyono, Muluk \& Haryono | Trade-offs Budget of Archipelagic Local Government in Indonesia

Sumenep Regency Government needs assistance from the upper government, namely the Provincial Government of East Java, and the Central Government.

\section{Conclusion}

Budget management in Sumenep Regency shows the behavior of trade-offs budget between the mainland and the archipelagic area. It is indicated by archetype success to the successful. The regions negate each other in budget allocations. Archipelagic local governments face challenges in geographical condition that needs strong financial capacity to realize even development in all regions.

Poor financial capacity results in a monopolistic pattern of budgeting. Local governments must prioritize in which the results prioritize one region and put other regions in the second priority. Besides, based on existing archetypes, such actions will result in trade-offs budget that trigger disparity between regions. If priority is given to the archipelagic area, the region can develop with the support of quality development, but it gives the impact on the decline of development performance in the mainland. Conversely, if the priority is given to mainland, the archipelagic area will make the development slower.

Trade-offs budget should be avoided as much as possible because it can cause development disparity. Then the development disparity triggers the occurrence of discatchment area. However, it is difficult for the Government of Sumenep Regency to overcome it because of its limited financial capacity. Therefore, the role of the government on it is needed. A multi-level government approach must be carried out with policy affirmations that make the archipelagic area as a priority area of national development that is followed with financial support. If it can be realized, it can ease the budget burden for Sumenep Regency Government as well as it can overcome development disparity in the region.

\section{References}

Adolph, Christopher, Christian Breunig, and Chris Koski. (2018) 'The political economy of trade offs budget”, Journal of Public Policy X: p1-26. https://doi.org/10.1017/S0143814X18000326

Bennett, R. J. (1980) The geography of public finance: welfare under fiscal federalism and local government finance. London: Methuen.

Bowon, Chang. (2010) The power of geographical boundaries: cultural, political, and economic border effects in unitary nation. Ames Iowa: Thesis in Iowa State University.

Caffrey, Louise, and Munro Eileen. (2017) 'A systems approach to policy evaluation', Evaluation Journal, ISSN1356-3890 (online). Available at: http://eprints.lse.ac.uk/83768/ (Accessed: 13 September 2018)

Darwanis, and Sephi Chairunnisa. 2013, 'Akuntabilitas kinerja instansi pemerintah', Jurnal Telaah \& Riset Akuntansi 6(2): p150-174.

Haines, Stephen G. (1998) Systems thinking and learning. Massachusetts: HRD Press.

Hoessein, B. (2000) 'Hubungan penyelenggaraan pemerintahan pusat dengan pemerintahan daerah', Jurnal Bisnis \& Birokrasi 1(1): p1-20.

Khan, Mohd. Akbar Ali, and M. A. Mutallib. (1982) Theory of local government. New Delhi: Sterling Publishers Private Limited. 
Kim, Daniel H., and Colleen P. Lannon. (1997) Applying systems archetype. Waltham: Pegasus Communication, Inc.

Kim, Daniel H., and Virginia Anderson. (1998) Systems archetype basics: from story to structure. Waltham: Pegasus Communication, Inc.

Krause, Goerge A., and Benjamin F. Melusky. (2012) 'Concentrated power: unilateral executive authority and fiscal policy making in the american states', The journal of Politics, 74 (OI): p98-112. https://doi.org/10.1017/S0022381611001149

Lewis, Daniel D., Saundra K. Schneider, and William G. Jacoby. (2015) 'Institutional characteristics and state policy priorities the impact of legislatures and governors', State Politics \& Policy Quarterly, 15 (4), p447-475. https://doi.org/10.1177/1532440015586315

MacCallum, Diana, et al. (2009) Social innovation and territorial development. Farnham, England: Ashgate Publishing Limited.

Muluk, M. R. Khairul. (2009) Peta konsep desentralisasi dan pemerintahan daerah. Surabaya: ITS Press.

Mulyana, Budi, et al., (2006) Keuangan daerah: perspektif desentralisasi fiskal dan pengelolaan apbd di indonesia. Jakarta: Lembaga Pengkajian Keuangan Publik dan Akuntansi Pemerintah.

Naab, Matthias Zana, 2005, Decentralization and democratic local governance in ghana: assessing the performance of district assemblies and exploring the scope of partnership. Dissertation in University of Pittsburgh.

Norton, A. (1994) International handbook of local and regional government: a comparative analysis of advanced democracies. Cheltenham: Edward Edgar.Parker, Andrew N. (1995) 'Decentralization: the way forward for rural development?', Policy Research Working Paper 1475, Washington D.C.: WorldBank.

Rondinelli, Dennis. (1999) 'What is decentralization?', Decentralization Briefing Notes, WBI Working Papers.

Rubin, Irene. (1997) The politic of public budgeting: getting and spending, borrowing, and balancing. 3rd ed. Chatham, New Jersey: Chatham House Publisher.

Said, M. Mas'ud. (2008) Arah baru otonomi daerah di indonesia. Malang: UMM Press.

Saragih, Juli Panglima. (2003) Desentralisasi fiskal dan keuangan daerah dalam otonomi. Jakarta: Ghalia Indonesia.

Silaban, Adanan. (2011) 'Pengaruh multidimensi komitmen profesional terhadap perilaku audit disfungsional', Jurnal Akuntansi \& Auditing, 8(1): p1-11.

Smith, B. C. (1985) Decentralization: the territorial dimension of the state. London: George Allen \& Unwin.

Tangkilisan, Hessel Nogi S. (2005) Manajemen publik. Jakarta: PT. Gramedia Widiasarana Indonesia.

Thurmaier, Kurt M., and Katherine G. Willoughby. (2001) Policy and politics in state budgeting., London: M. E. Sharpe.

Worthington, A. C., and B. E. Dollery. (2001) 'Measuring efficiency in local government: an analysis of new south wales municipalities' domestic waste management function', Policy Studies Journal, 29(2): p232-250. https://doi.org/10.1111/j.1541-0072.2001.tb02088.x 